\title{
XXXIII. Latent heat of evaporation of zinc and cedmium
}

\section{William Sutherland}

To cite this article: William Sutherland (1898) XXXIII. Latent heat of evaporation of zinc and cedmium , Philosophical Magazine Series 5, 46:280, 345-346, DOI: 10.1080/14786449808621202

To link to this article: http://dx.doi.org/10.1080/14786449808621202

曲 Published online: 08 May 2009.

Submit your article to this journal $[\pi$

Џ Article views: 5

Q View related articles $\asymp$ 
XXXIII. Latent Heat of Evaporation of Zinc and Cadmium. By William Sutherland*

TN an article on the Fundamental Atomic Laws of Therme1 chemistry (Phil. Mag. [5] vol. xl. 1895), certain principles as to molecular force were used to calculate the latent heats of evaporation of metals and compounds of metals. At the time of these calculations it escaped my notice that Barus, in his article on the Pressure-variation of certain Highpressure Boiling-points (Phil. Mag. [5] vol. xxix. 1890), had supplied data whereby the latent heats of vaporization of zinc and cadmium could be determined. It therefore seems desirable to show briefly now how the theoretical agres with the experimental determinations.

The nsual thermodynamical equation for the latent heat of eraporation of a gramme of liquid at absolute temperature $\theta$ and of volume $v_{1}$ into saturated vapour of volume $v_{3}$ at saturation-pressure $p$,

$$
\lambda=\theta \frac{d p}{d \theta}\left(v_{3}-v_{1}\right) / \mathrm{J},
$$

hats been so thoroughly verified that it furnishes an experimental method of determining $\lambda$ without the necessity of direct calorimetric measurements. Let $M$ be the molecular mass of the substance, that of hydrogen being 2 ; then neglecting $r_{1}$ beside $r_{3}$, we have

$$
\mathbf{M} \lambda=\theta \frac{d p}{d \theta} \mathrm{M} r_{3} / \mathrm{J}
$$

Now for 2 grammes of hydrogen under standard conditions $\mathrm{M} v_{3}$ is 22,400 c. c.; so that for a vaporized metal at a pressure of 1 atmo and at $\theta$ the value of $M v_{3}$ is $22400 \theta / 273$.

For the relation between $p$ and $\theta$ for $\mathrm{Zn}$ and $\mathrm{Cd}$, Barus gives formulæ which represent bis experinental results satisfactorily, and enable one to calculate $d p / d \theta$ at values of $p$ from 1 atmo down to a fraction thereof. Using the constants of the formula at p. 152 of his paper, we find for $(d p / d \theta) \theta / p$ when $p$ is 1 atmo the value 11.9 for $Z n$, and $14 \cdot 2$ for $\mathrm{Cd}$, the corresponding values of $\theta$ being 1200 for $\mathrm{Zn}$ and 1050 for (d. Thus, then, taking 1 atmo as $1.014 \times 10^{6}$ dynes per cm. ${ }^{2}$, and $J$ as $42 \times 10^{6}$ ergs, we obtain as the values of $M \lambda$ in kilocalories $28 \cdot 3$ for $\mathrm{Zn}$ and $29 \cdot 6$ for $\mathrm{Cd}$ : these are the heats of vaporization of gramme-molecules of these metals as liquids. Now Person's values (Ann. de Ch. ei de Phys. [3] xxiv.) for the latent heats of fasion of $\mathrm{Zn}$ and cu per gramme-molecule in kilocalories are 1.8 and 1.5 ; so that the total heats of volatilizing grammemolecnles of solid $\mathrm{Zn}$ and $\mathrm{Cd}$ are $30 \cdot 1$ and $31 \cdot 1$. These numbers include the heat used in expanding the evaporating

* Communicated by the Author. 
metal against the atmospheric pressure, which for most liquids has been found to be about one-eleventh of the total latent heat. Thus for the raporization of a gramme-molecule of solid Zn and of solid $\mathrm{Cd}$, without performance of external work; we have the approximate values 27 and 28 respectively, while the value adopted on p. 18 of my paper is $29 \cdot 6$ for both of them. This agreement should increase the confidence to be placed in the estimates of the latent. hents of the otber metals and compounds given in that paper. It should interest thermochemists to learn that the work of Barus shows how a number of important latent heats can be determined experimentally with the aid of thermodynamics.

XXXIV. Proceedings of Learned Societies. GEOLOGICAL SOCIETY.

[Continued from p. 260.]

May 18th, 1898. - W. Whitaker, B.A., F.R.S., President, in the Chair.

THE following communications were read:-

1. 'The Garnet-actinolite Schists on the Southern Side of the St. Gothard Pass.' By Prof. T. G. Bonuey, D.Se., LL.D., F.R.S., V.P.G.S.

The author describes the field relations and the microscopic structures of a group of schists or gneisses characterized by the frequent presence of conspicuous garnets and actinolites, which are exposed on the southern slopes of the St. Gothard Pass and for some distance west and east, on the northern side of the Val Bedretto. These, called for purposes of reference the Tremola Schists, he has examined from time to time since 1878 , the last oceasion being the summer of 1897 , when he was accompanied and aided by Mr. John Parkinson, F.G.S. These rocks in the field might be regarded as highly-altered sedimentary strata (as the author once thought) or as a group of igneous rocks (originating possibly in magmatic differentiation) affected by fluxion-morements anterior to consolidation. To the latter view he now inclines, but considers the schistosity and the peculiar minor structures to be the results of crushing (generally without marked shearing) followed by rery considerable mineral reconstruction. The garnets he holds to be anterior to this crushing, but the larger biotites and the conspicuous actinolites to be posterior to it. These minerals, in his opinion, throw some light on processes of crrstallization in rocks more or less pulverized, or, in other words, in the presence of various impediments. He thinks it probable that the Tremola Schists assumed their present form prior to the great Tertiary earth-movements which gave rise to the existing Alpine chain.

2. 'On the Metamorphism of a Series of Grits and Shales in Northern Anglesey.' By C. Callaway, M.A., D.Sc., F.G.S.

These rocks occur in a patch about 3 miles square, situated south-west of Amlwch, and extending from Llanfechell and Rhos- 